\title{
HOW THE HOME MATCHES THE PERSON: THE RELEVANCE OF THE HOME ENVIRONMENT QUESTIONNAIRE
}

\author{
S.I. REZNICHENKO ${ }^{a}$, S.K. NARTOVA-BOCHAVER ${ }^{\text {b }}$, E.I. BRAGINETS ${ }^{b}$
}

${ }^{a}$ Moscow State University of Psychology and Education, 29 Sretenka Str., Moscow, 127051, Russian Federation

${ }^{b}$ National Research University Higher School of Economics, 20 Myasnitskaya Str., Moscow, 101000, Russian Federation

\begin{abstract}
In a questionnaire study with $\mathrm{N}=1730$ participants aged from 11 to 72 years $(\mathrm{M}=20.4, \mathrm{Me}=19$, $\mathrm{SD}=6.96), 60 \%$ female, we developed the Relevance of the Home Environment Questionnaire (RHEQ) aimed at measuring parameters of the home environment as the inhabitants' eco-social resource. Results from exploratory and confirmatory factor analyses showed that the seven-factor structure of the questionnaire was uniquely formulated. The scales were titled as follows: Privacy, Potential, Self-presentation, Ergonomics, Home detachment, Plasticity, and Historicity. Consistency coefficients (Cronbach's alpha) of scales ranged from .91 to .94. Age trends in four out of seven scales were found. Potential scores were higher in women, while Home detachment - in men. Content validity was investigated by comparison of home relevance scores in students living in their own homes or dormitories. Convergent validity was explored by measuring correlations of the scales with the Functionality of the Home Environment Questionnaire and the Home Attachment Scale. All psychometric properties are satisfactory. Data was discussed with regard to possible applications in research, expertise, and psychotherapy.
\end{abstract}

Keywords: home environment, person-environment fit, validation, relevance, affordance, functionality, home attachment.

\section{Introduction}

Seeking ecological and healthy ways to stimulate one's well-being and growth is one of the most important trends in today's psychology (Moser, 2009; Horelli \& Prezza, 2004). Ironically, the home as the very basic "оскоs" has not attracted until now much research focus. Home is the primary, basic and relatively constant space in human life that meets a person's basic needs, stimulates development and also carries a psychotherapeutic function. Even when a person has no home, the home's image itself appears to be the source of a person's support (Bochaver, 2015; Dovey, 1985; Case, 1996; Nartova-Bochaver, Bochaver, Dmitrieva, \& Reznichenko, 2016;

This research was supported by the Russian Science Foundation (Project 14-18-02163). 
Nartova-Bochaver, Reznichenko, Braginetc, \& Podlipnyak, 2015). At the same time, research on relationships between home and its inhabitants has been hampered by the lack of a valid measure. Methodological tools in environmental psychology primarily allow us to estimate only the physical attributes of a dwelling (location, footage, furnishings) but rarely take into account the individual needs of each inhabitant (Boumeester, 2011; Bradley, Caldwell, \& Elardo, 1979; Heft, 1979, 1985; Jansen, Coolen, \& Goetgeluk, 2011). Furthermore, usually there are either interviews or projective techniques that are used as research methods, therefore the results may not be unambiguous and often need additional verification (Skifter Andersen, 2011), except some initial inventories developed for children's home environments decades ago (e.g., Bradley et al., 1979; Heft, 1979, 1985). There exist only few for assessing the psychological resources of environment for adult individuals, and there are no such tools in Russia at all. This is due to the multidimensionality of the concept of home and, therefore, different points of the analysis of relationships between home and its inhabitants.

Researchers and theorists have presented a variety of definitions for the concept of home. P. Somerville (1992) argued that home has at least six dimensions of meaning identified by the 'key signifiers' of shelter, hearth, heart, privacy, roots and abode. After G. Hayward (1975), home can be considered as a physical structure, a territory, a locus in space, self and self-identity, a social and cultural unit. A. Rapoport (1995) referred to three semiotic units of living environment: 1) home as a building with its spatial characteristics, architecture and design; 2) home as a dwelling (functional space) where a person performs various daily activities; 3 ) home as a place with intrapersonal meanings (meanings). In similar way, $\mathrm{H}$. Coolen and J. Meesters (2012) suggest sharing the concepts of house, dwelling and home. 'House' is commonly used in housing research and describes the physical objective structures we live in. A dwelling is defined as a system of settings that affords different functions and activities (eating, relaxing, entertaining, etc.). While the concept of home connotes with positive feelings and affective bonds based on the temporal (e.g. home as the place where one was born) and social (e.g. home as a "family nest") individual experience and meanings we attach to the living space.

We understand home as integrity of physical, social, and existential properties of a specific place satisfying inhabitants' needs (for security, comfort, identity, etc.). In the normative case, home is present through the course of the life of a person, is biographically connected with his/her history and therefore reflects individuality, expresses identity and stimulates personal authenticity. Following the Lens model of Brunswik (1956), Gibson's theory of affordances (1986), Person-Environment Fit theory (Edwards, Caplan, \& Harrison, 1998; Kahana, Lovegreen, Kahana, \& Kahana, 2003), the concept of environmental friendliness (Chemero, 2003; Coolen, 2011; Coolen \& Hoekstra, 2001; Greeno, 1994; Horelli, 2007; Horelli \& Prezza, 2004; Kyttä, 2004) and the subject-environmental approach (Nartova-Bochaver, 2008), we believe that the interaction between a person and their home occurs on several levels.

The non-psychological level defines a place as a house, but not as a home. This level is set by the quality of housing, - for example, its location, type, size or number of inhabitants sharing the same living space. 
The objective level is set by the physical qualities of home as a living environment represented in the degree of functionality of the home environment - various functions and activities that home performs for its inhabitants (i.e. meeting the needs for privacy, development, health management, communication with family members, etc.). Initially the functions of home environment can't be maladaptive (Gosling, Ko, Mannarelli, \& Morris, 2002). The more functions a home can perform, the higher number of people it can potentially fit, but the presence of a large number of different functions does not necessarily make it an "ideal home", because some functions are unconscious due to their irrelevance for a particular person (for example, a playground near the house won't be a significant attribute of the home environment for families without children).

The intermediate level, or the relevance of home environment, is a degree to which the inhabitant's needs and environmental characteristics match. This level includes a system of affordances - dispositional properties of environments and functionally meaningful 'relations between abilities to perceive and act and features of the environment' (Chemero, 2009, p. 150). The process of perceiving affordances is not the same for all people sharing the same space as others' bodily features and values differ from ours. According to the theory of environmental friendliness the more affordances the environment includes, the friendlier it is to its inhabitant (Chemero, 2003; Coolen, 2011; Kyttä, 2004). As H. Coolen (2011) wrote, "Individuals selectively engage particular objects in their surroundings; individuals typically make choices from among the range of potential features in a setting to support some activity. However, individuals do not have unconstrained choice. $<\ldots>$ So there is self-selection of affordances but often within constraints" (p. 5).

Finally, the deepest level of psychological analysis shows the people-home relationship is subjective. The subjective level reflects a system of personal experiences and meanings, positive feelings and attitudes towards a home that are integrated into a sense of home attachment de ned as a complex of positive experiences and feelings toward home as a personally relevant place in functional, emotional and symbolic meanings. We assume that home attachment is a kind of place attachment and has a similar structure, manifestations and development mechanisms (Jorgensen \& Stedman, 2006; Lewicka, 2011; Reznichenko, 2014; Scannell \& Gifford, 2017). Home attachment positively affects the psychological health, well-being and authenticity (Manzo, 2003; Reznichenko, 2016).

We previously developed a set of tools that only allowed the study of two levels of person-home interaction: The Functionality of the Home Environment Questionnaire (FHEQ) was designed to assess the objective level and measure various functions presented in the home environment so that an objective level is possible in relation to the home (Nartova-Bochaver, Dmitrieva, Reznichenko, Kuznetsova, \& Braginets, 2015); the second one, Home Attachment Scale (HAS), allows the exploration of the subjective level of analysis and measures the person-to-home emotional bonds (Reznichenko, Nartova-Bochaver, \& Kuznetsova, 2016). In this article, our aim was to describe a technique that allows measuring how much the inhabitants feel their home suits them, reflects their individuality and meets their 
basic needs; a subjectively perceived preference of what we call a relevant home. In other words, we would investigate the "compatibility" between people and their home that represents the intermediate level (subject-environmental) of personhome relationship.

As Heft (2012) rightly noted, to proceed in making an assessment of the psychological resources, several steps are required: "(1) particular possibilities need to be proposed for what may serve as an eco-psychological resource (e.g., a particular type of affordance); (2) a means of assessing the availability of these resources in some local needs to be developed; and crucially, (3) linkages between availability of these resources and positive outcomes must be established" (Ibid., p. 26). And we can say, in the current study, these steps towards development of the multi-factorial questionnaire have been taken into consideration.

\section{Participants and Procedure}

Sample. In total, 1730 respondents aged from 11 to $72\left(M_{a g e}=20.4 ; M e_{a g e}=19.0\right.$, $S D_{a g e}=6.96,62,2 \%$ female) participated in our surveys. Most respondents were recruited from Moscow universities. Adult respondents were recruited mainly from students' families using the technique that became known as "snow ball". Participation in the survey was absolutely voluntary, students were granted an academic credit as compensation. The program of the survey was approved by the Ethical Committee of the National Research University Higher School of Economics. The survey was realized using the "patchwork" design: not all respondents participated in all studies but most of them did. Sample 1 (preliminary study, development of the item pool $)$ included 186 participants, Muscovites, $\left(M_{a g e}=23.9\right.$, $S D_{a g e}=4.9,55.9 \%$ female). Sample 2 (exploratory analysis, reducing the number of questionnaire items) consisted of 431 participants from Moscow and other regions, students from different faculties $\left(M_{a g e}=20.5, S D_{a g e}=10.1,72.2 \%\right.$ female $)$. Sample 3 (factor analysis, internal consistency) comprised of 1051 participants from Moscow and other regions, students from different faculties $\left(M_{a g e}=20.5, S D_{a g e}=\right.$ 10.1, 72.2\% female). Sample 4 (external validity: age trend and gender differences) included 332 respondents $\left(M_{a g e}=26.8 ; S D_{a g e}=13.2 ; 54.8 \%\right.$ female) divided into four age groups (82 adolescents $12-17 ; 76$ young adults aged $18-24 ; 87$ adults aged $25-$ 45, and 87 late adults aged 46-72. Sample 5 (content validity) included 434 respondents. 227 of them were Muscovites living with their parents mostly, all single $\left(M_{a g e}=22.1, S D_{a g e}=0.92 ; 71.6 \%\right.$ female $)$. Other 207 came to Moscow from different regions of Russia and lived in dormitories where they had to share their rooms with $2-3$ other students $\left(M_{\text {age }}=21.7, S D_{\text {age }}=0.65 ; 78.7 \%\right.$ female). Sample 6 (construct validity) consisted of 719 individuals aged from 18 to $40\left(M_{\text {age }}=21.92\right.$, $S D_{\text {age }}=6.90 ; 71.2 \%$ female), who were students and graduates from Moscow universities.

We used web-based data collection. The respondents were required to fill out questionnaires incorporating a forced-choice question format. There was no time limit to complete the questionnaires. 
Measures. The Functionality of the Home Environment Questionnaire (FHEQ) and The Home Attachment Scale (HAS) were used to measure the convergent validity of the new instrument.

FHEQ was aimed to assess the functions provided by the home to its dwellers (Nartova-Bochaver et al., 2015). The questionnaire consists of 55 statements and four subscales (Pragmatism, Development, Stability, and Protection). Examples of FHEQ items are as follows: "My home ... 1) demonstrates the dwellers' wealth, 2 ) is accessible (geographically and financially), 3) is spacious 4) gives an opportunity to care for myself, etc. In the current study, Cronbach's alphas were from 0.82 to 0.93 for all subscales.

The Home Attachment Scale (HAS) indicates the level of a person's positive emotional connectedness to his/her home (Reznichenko et al., 2016). It includes 14 statements and only one scale. Examples of the items are as follows: "I identify myself strongly with my home", "My home says a lot about who I am", "I am willing to put my heart and soul into my home". In this study, alpha was 0.89 .

\section{Results}

\section{Development of the Item Pool}

To collect a prior pool of statements, firstly we analyzed the sources in the fields of social, environmental, recreational psychology and social anthropology to identify the person's needs satisfied by their home (Boumeester, 2011; Coolen, 2011; Depres, 1991; Ingold, 2002). Then, during the empirical research, the list of constructs identified theoretically was enlarged (Sample 1). Participants (Sample 1) were invited to take part in a ladder interview on the topic of the desired image of a home. Also, respondents were asked to evaluate interiors of rooms and dwellings using the minimum context method by Kelly and to name the meaningful home qualities (Kelly, 1991). Finally, we used a number of creative tasks such as incomplete sentence test and essay exercises.

As a result, this study has identified 54 characteristics of home environment that meet multilevel needs of inhabitants (for rest, for safety, for family interaction, for home space changeability, for ergonomics and aesthetics, for self-presentation and self-development, etc.). Two statements were formulated for each construct (total 108 statements); the questionnaire items' wording had to reflect the personal opinion of the respondent on the possibilities of his own home. The ratio of inverse and direct statement formulations were 1:7. The degree of agreement/disagreement with the statements was evaluated on a five-point Likert scale. To ensure the respondents understood the instruction and to correct controversial statements, a focused interview was conducted. The primary version of the questionnaire was offered to the group of respondents (Sample 1) for feedback on the content, structure and clarity of the statement wordings for convenience of filling out the questionnaire.

Next, we conducted an Exploratory Factor Analysis (EFA) to determine the preliminary structure of the questionnaire and narrow down to the number of variables 
(Sample 2). The method of Principal Components Analysis (PCA) with Varimax rotation was used to calculate factors. The criterion of Kaiser's eigenvalues $(k>1)$ showed only one optimal model consisting of seven factors. Since sometimes this criterion shows an inadequately large number of factors, an additional Scree-plot test was performed that confirmed the seven-factor structure. The EFA allowed us to reduce all the items with low factor loadings and to reduce the questionnaire length from 108 statements to 35 items ( 5 items per scale).

\section{Dimensional Structure of the RHEQ}

The reduced version of the questionnaire was reanalyzed with EFA using the Varimax rotation of factors. As previously the seven-factor solution was revealed (the questionnaire structure with factor loadings is presented in Figure 1). We used the final statement list in our further work on this questionnaire (Appendix A).

The performance of the model was evaluated (Sample 3) by examining the ensemble of "goodness-of-fit" statistics, such as the Root Mean Squared Error of

\section{Factor Loadings of the Seven-Factor Solution of RHEQ}

Figure 1

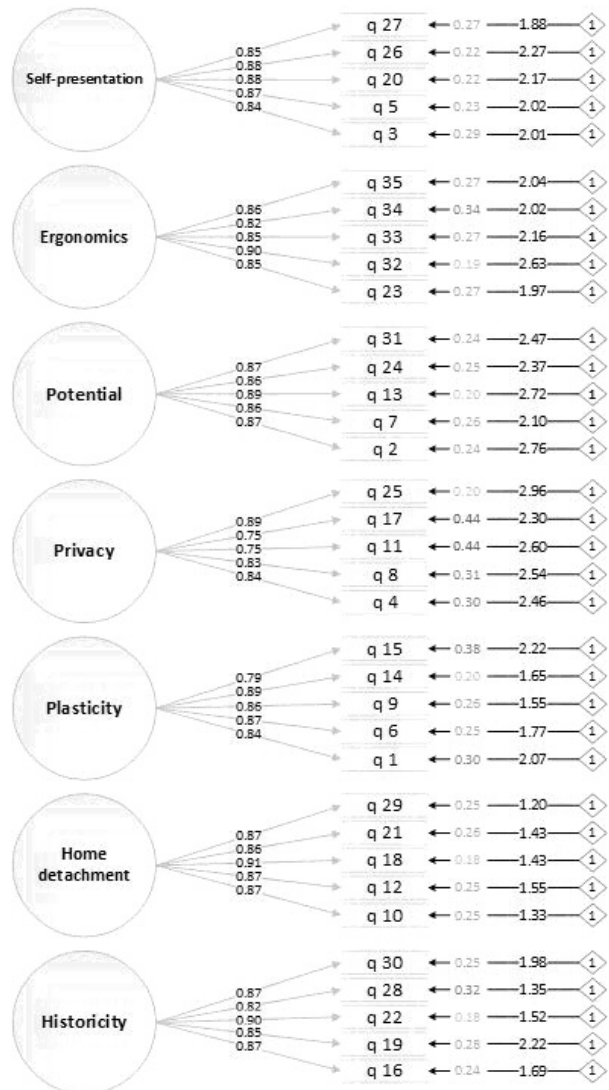


Approximation (RMSEA), Standardized Root Mean Square Residual (SRMR), the Comparative Fit Index (CFI) and Tucker Lewis Index (TLI). According to conventional agreements, all the indices except chi-squared test indicate a good fit of model (CFI $>0.9$, TLI $>0.9$, SRMR $<0.5$ ) (Hooper, Coughlan, \& Mullen, 2008). The insufficient level of chi-squared significance can be explained by a large sample (>200), so the Chi-Square statistic nearly always rejects the model in this case (Bentler \& Bonnet, 1980). Table 1 shows the results of confirmatory factor analysis.

The titles of the scales were as follows. (1) Self-presentation is associated with the inhabitants' possibility to personalize their own space and to signify the individual and social characteristics of the dwellers through the home environment. (2) Ergonomics describes home environment convenience and aesthetics. (3) Potential includes constructs associated with home support and stability. (4) Privacy is associated with the capability to control and predict a home environment context. (5) Home Detachment is concerned with reasons of home estrangement, loss of home attachment and sense of belonging. This scale includes statements related to discomfort, inconvenience, low functionality of a living space, and lack of desire to come back home. We have not reversed this scale (i.e. haven't measured 'home detachment' in a positive direction) to prevent confusion with the concept of Home Attachment. (6) Plasticity determines the capability of the home environment to be dynamic in accordance with the changing resident's needs. (7) Historicity reflects the links of a home with the personal, family, and general past.

The average score is calculated for each subscale. Evaluation of the overall level of home environment relevance is performed by summing up the average values of seven scales, except for the Home Detachment scale, the rate of which is subtracted from the total.

\section{Descriptive Statistics and Internal Consistency}

Table 2 shows the descriptive statistics and unexpectedly high coefficients of internal consistency (taking into account the small number of items in each scale) ranging from .91 to .94 . Thus, we have obtained initial norms; all Cronbach's alpha values are satisfactory confirming the test to be highly reliable.

The most considerable variability is revealed in Historicity and Self-presentation scores, this potentially indicates that the intensity of these needs depends more on latent variables, for example, the respondent's gender or age. Privacy scale has the lowest variability of scores - probably this need is the most universal and significant for the whole population.

Table 1

Goodness-of-Fit Statistics of the Seven-Factor Model of RHEQ (N = 1051)

\begin{tabular}{|c|c|c|c|c|c|c|}
\hline Model & $\chi^{2}$ (p-value) & df & RMSEA & SRMR & CFI & TLI \\
\hline Seven factors & $4248.2(0.00)$ & 539 & .06 & .03 & .94 & .94 \\
\hline
\end{tabular}


Table 2

Descriptive Statistics of the RHEQ Scales $(\mathrm{N}=1051)$

\begin{tabular}{|l|c|c|c|c|c|c|c|}
\hline \multicolumn{1}{|c|}{ Scales } & M & SD & Me & Min & Max & SE & Cronbach's alpha \\
\hline Self-presentation & 3.36 & 0.90 & 3.40 & 1 & 5 & 0.02 & .94 \\
\hline Ergonomics & 3.45 & 0.85 & 3.40 & 1 & 5 & 0.02 & .93 \\
\hline Potential & 3.80 & 0.86 & 4.00 & 1 & 5 & 0.02 & .92 \\
\hline Privacy & 3.92 & 0.73 & 4.00 & 1 & 5 & 0.02 & .91 \\
\hline Home detachment & 2.35 & 0.85 & 2.20 & 1 & 5 & 0.02 & .94 \\
\hline Plasticity & 3.09 & 0.88 & 3.20 & 1 & 5 & 0.02 & .94 \\
\hline Historicity & 3.07 & 1.10 & 3.00 & 1 & 5 & 0.03 & .94 \\
\hline
\end{tabular}

\section{External Validity}

External validity of the questionnaire was evaluated via ANOVA and post hoc analysis of the variances in different ages and gender populations (Sample 4).

Age trends. Although there were not significant differences between age groups $\left(F_{3: 329}=0.632 ; p=.590\right)$ regarding general index of RHEQ, they were found in four of the seven scales in the questionnaire, namely: Potential $\left(F_{3: 329}=5.955 ; p=.001\right)$, Ergonomics $\left(F_{3 ; 329}=4.792 ; p=.003\right)$, Plasticity $\left(F_{3 ; 329}=9.423 ; p=.000\right)$, and Historicity $\left(F_{3 ; 329}=5.637 ; p=.001\right)$ (Figure 2). The Games-Howell post hoc test allowed obtaining the following results. In late adulthood Potential of the home scale index is significantly higher than in adults $(p \leqslant .050)$, young adults $(p \leqslant .002)$, and especially in adolescents $(p \leqslant .000)$. Ergonomics indices are significantly higher in adolescents than in young adults $(p \leqslant .047)$ and in adults $(p \leqslant .002)$. Plasticity is equally less significant in adolescents and young adults, than in adults $(p=0.001$ and $p=.006$, respectively) and in late adults ( $p=.000$ and $p=.002$, respectively): flexible home is more important in adulthood than in youth. Finally, adolescents and young people had higher scores ( $p=.004$ in both groups) on the Historicity scale than the adults.

Gender differences. Analysis of gender differences showed that Home Detachment $\left(F_{1 ; 331}=5.804 ; p \leqslant .017\right)$ is higher in the male group, while Potential scores $\left(F_{1 ; 331}=4.114 ; p \leqslant .023\right)$ are higher in women.

\section{Content Validity}

In order to test whether RHEQ adequately reflects real significance (relevance) of the home affordances for its inhabitant, we compared the data of students who lived in parental homes or their own apartments, and those who resided in dormitories.

Comparing RHEQ indices of students with different living conditions (using ANOVA), we found that those who lived in their own homes have a higher overall RHEQ rate $\left(F_{1: 433}=85.681 ; p \quad .000\right)$ than others as well as rates of all the 'positive' scales: Privacy $\left(F_{1 ; 433}=34.641 ; p \leqslant .000\right)$, Self-presentation $\left(F_{1 ; 433}=27.451 ; p \leqslant .000\right)$, 
Ergonomics $\left(F_{1 ; 433}=38.378 ; p \leqslant .000\right)$, Plasticity $\left(F_{1: 433}=34.752 ; p \leqslant .000\right)$; high intergroup differences were especially observed in Potential $\left(F_{1: 433}=74.440 ; p \leqslant .000\right)$ and Historicity $\left(F_{1: 433}=64.943 ; p \leqslant .000\right)$ scores. At the same time, Home Detachment indices are lower in this group of respondents $\left(F_{1: 433}=6.272 ; p \leqslant .013\right)$. This data is presented in Figure 3 .

\section{Construct Validity}

The construct validity of the questionnaire was evaluated by examining its correlation to the closest in terms of content empirical constructs - Functionality of

Age Differences in Mean Scores of the RHEQ scales $(\mathrm{N}=332)$

Figure 2

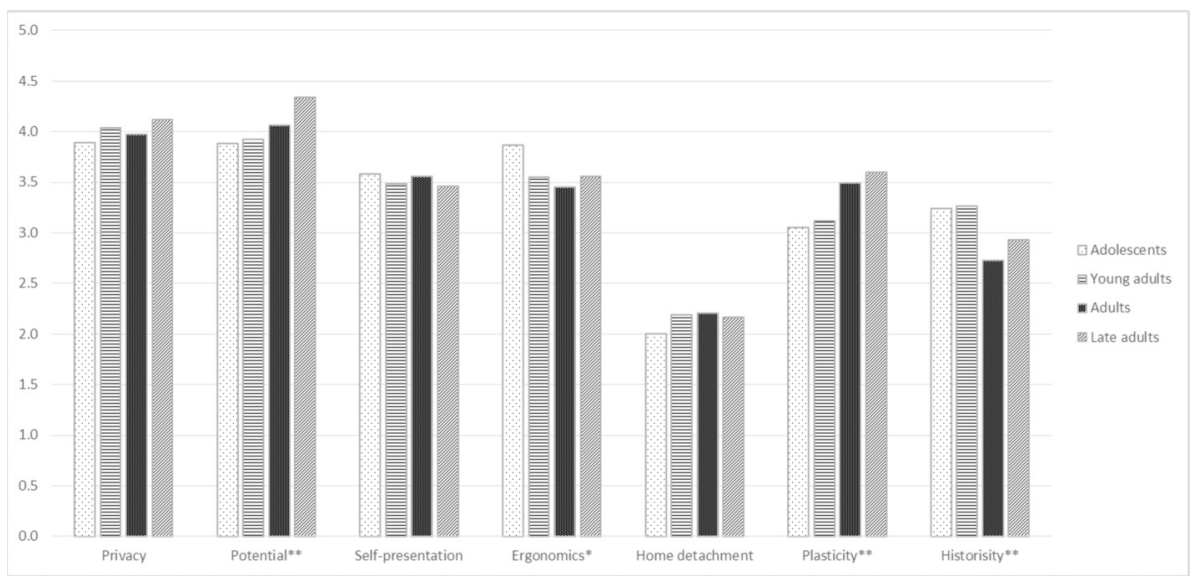

${ }^{*} p \leqslant 0.01,{ }^{* *} p \leqslant 0.001$.

Figure 3

The Differences of Mean Scores $(p \leqslant 0.001)$ of the RHEQ Scales in Students Living in Their Own Flats, and Dormitories $(N=434)$

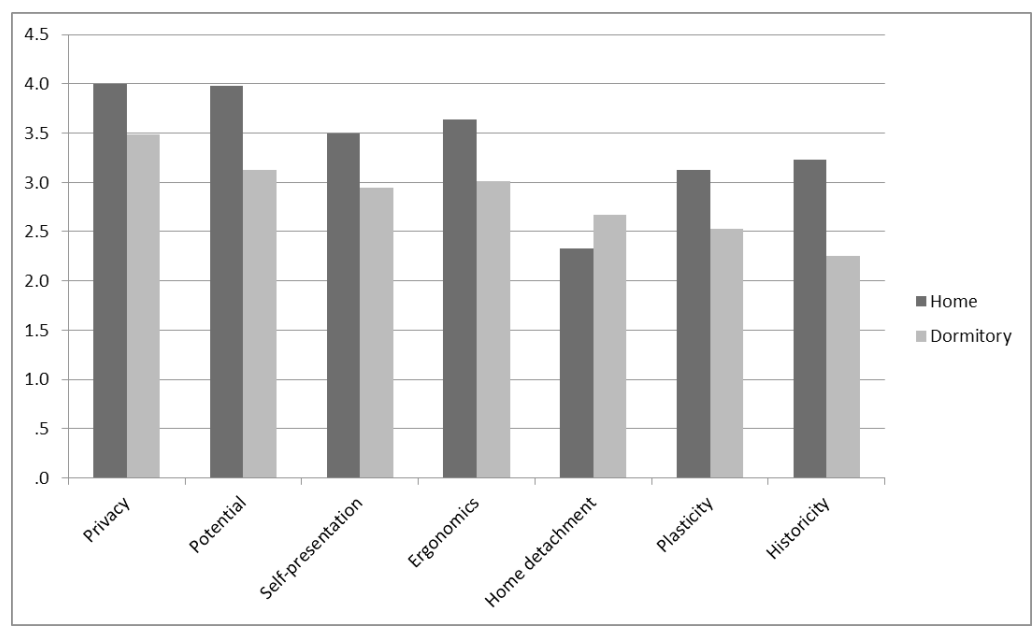


the Home Environment (is measured by the FHEQ) and Home Attachment (HAS) were used. As shown in Table 3, all the scales of RHEQ, except the Home Detachment scale, have a significant positive relationship $(p \leqslant .000)$ with the scales of the FHEQ and Home Attachment scale, while Home Detachment has significant negative relations $(p \leqslant .000)$. The strongest correlations are found between Potential, Ergonomics, Self-presentation and the FHEQ and Home Attachment scales. A weak negative correlation was received only between the Home Detachment and Protection scales.

\section{Discussion}

Based on the Theories of Affordances (Gibson, 1986) and Person-Environment Fit (Coolen \& Hoekstra, 2001; Horelli, 2007; Kyttä, 2004) as well as on multidisciplinary works devoted to wholesome impacts of the home environment on individuals' well-being (Casakin \& Bernard, 2012; Heft, 2012; Ingold, 2002) the Relevance of the Home Environment Questionnaire was developed. The aim of this instrument is to measure the extent to which the affordability of home is able to meet the various needs of the dwellers (relevant to dwellers).

While creating the initial statements pool, we assumed the understanding of the home both as the archetypal phenomenon and as a private living space at the same time. That is why in the very beginning we selected from multidisciplinary sources those well-known functions that home had in different times and cultures. Then, through a series of empirical studies, this list was enlarged by functions, which are performed in homes of modern Russians in their everyday lives. Since there is a high diversity in living conditions in Russia, and traditional Russian families are

Table 3

Correlations between the Relevance of the Home Environment Questionnaire (RHEQ) Scales, the Functionality of the Home Environment Questionnaire (FHEQ) scales, and the Home Attachment scale (HAS) $(\mathrm{N}=\mathbf{7 1 9})$

\begin{tabular}{|l|c|c|c|c|c|c|}
\hline \multicolumn{1}{|c|}{ RHEQ Scales } & \multicolumn{6}{c|}{ FHEQ Scales } \\
\hline & FHE & Pragmatism & Development & Stability & Protection & HAS \\
\hline RHE & $.78^{*}$ & $.76^{*}$ & $.72^{*}$ & $.71^{*}$ & $.60^{*}$ & $.64^{*}$ \\
\hline Privacy & $.69^{*}$ & $.71^{*}$ & $.60^{*}$ & $.67^{*}$ & $.49^{*}$ & $.59^{*}$ \\
\hline Potential & $.58^{*}$ & $.58^{*}$ & $.51^{*}$ & $.55^{*}$ & $.40^{*}$ & $.67^{*}$ \\
\hline Self-presentation & $.63^{*}$ & $.54^{*}$ & $.54^{*}$ & $.54^{*}$ & $.63^{*}$ & $.55^{*}$ \\
\hline Ergonomics & $.68^{*}$ & $.64^{*}$ & $.60^{*}$ & $.64^{*}$ & $.54^{*}$ & $.53^{*}$ \\
\hline Home detachment & $-.38^{*}$ & $-.44^{*}$ & $-.30^{*}$ & $-.38^{*}$ & $-.24^{*}$ & $-.31^{*}$ \\
\hline Plasticity & $.55^{*}$ & $.54^{*}$ & $.50^{*}$ & $.49^{*}$ & $.44^{*}$ & $.46^{*}$ \\
\hline Historicity & $.46^{*}$ & $.37^{*}$ & $.58^{*}$ & $.35^{*}$ & $.32^{*}$ & $.42^{*}$ \\
\hline
\end{tabular}

$* p \leqslant 0.01$. 
multigenerational, these constructs reflect the experiences associated with living in different dwellings such as separate rural houses, buildings with a few apartments or apartment blocks. This has contributed to the representation of the test statements and the expansion of the target audience within its users (e.g. researchers, practitioners).

Due to exploratory and confirmatory factor analyses seven scales were identified: Privacy, Potential, Self-presentation, Ergonomics, Home Detachment, Plasticity, and Historicity scales. The new tool seems to have good psychometric properties: Cronbach's alphas are ranged between .91 and .94. Investigation into age trends showed that the RHEQ scores environment features formed specific patterns (profiles) in every one of the investigated ages. Thus, the Potential and Plasticity scales have highest meanings in late adults, in full accordance with life styles of elderly people who usually spend a lot of time at home and get support and stability from their homes mainly, but not from jobs. Similar trends are shown in M. Lawton and L. Nahemow's (1973) ecological model of aging (Competence-Press Model theory) that conceptualizes the individual as having a set of competences, and the environment as a 'press' or having the characteristic of making demands upon the individual. As the levels of competence gradually decrease with age (due to age health problems, tendency to social and physical inactivity, decreased functioning of the nervous system, etc.), adaptation to living conditions requires a flexible, adaptable, and stable living environment.

At the same time, Historicity scores are higher in adolescents and youth because as the proportion of life experience just in their current houses is higher in these age groups, than it is for the older group. Finally, Ergonomics of the home environment is more relevant for teenagers than for older people. This may be due to the fact that the home for a teenager is not only a place of relaxation and recovery, but also a place for doing homework and networking with classmates that requires comfortable user-friendly conditions (Jonkmann, Thoemmes, Lüdtke, \& Trautwein, 2014). The Privacy, Self-presentation and Home Detachment (in terms of opposing positive connotations - the overall satisfaction with the living environment) scales have no differences that are age dependent, probably emphasizing the universal nature of these needs.

We have also found gender differences: Home Detachment scores are higher in men while Potential scores are higher in women. Whereas women are mostly the ones who engage in housekeeping and more often than men work from home, they need affordable, stable and supportive living environments at home to facilitate different home activities. At the same time, men do not cope with domestic problems as easily as women do (Graham \& Graham, 1989).

Calculation of the RHEQ scores in the samples of respondents living in different conditions (homes and dormitories) showed that all meanings were higher in students living in homes, and the Home Detachment score was significantly lower, thus giving good evidence for construct validity of the new tool. This is the expected result, because students who live in their own or their parents' homes are less limited in residential facilities and are not constrained by the rules and requirements of communal housing as experienced by dormitory residents. 
The correlation between the RHEQ and other environmental tools (FHEQ and HAS) was significant and positive, whereas the Home Detachment scale formed significant negative links with them. This confirms a good convergent validity of the new questionnaire: numbers of home functions as well as attachment to homes are in mutual relationship to the extent to which a home matches its inhabitants. Naturally, people who are attached to their homes personalize them more strongly and, in turn, this makes their homes more congruent to them.

To sum up, all these results uniquely demonstrate the good psychometric properties of the new instrument.

\section{Conclusions and Limitations}

The aim of the study was to develop the Relevance of the Home Environment Questionnaire as a tool to assess the person-home fit. It was stimulated by a broad list of applied tasks as follows: seeking empirical proof to the apartment-therapy, expertise of living spaces, the exploration of restorative and potential functions in various building environments, design of dwellers-friendly flats, homes, dormitories, hostels, hospitals, etc. The new RHEQ tool appears to be very helpful in solving these problems.

Before discussing further implications, we want to point out some limitations of the current study. Firstly, most tests of the RHEQ validity were realized in a students' sample. Secondly, our work did not deal with data on objectively verifiable characteristics of home (density, availability of personal space, length of residence, etc.), which makes the RHEQ content validity slightly less convincing. In future research we plan to observe the objective home characteristics more carefully.

At the same time, the development of RHEQ allows further testing of the theoretical positions, in addition to examining the questions that emerge from this article. For example: How does home as a physical space determine family climate? How does home influence the work-family balance in the inhabitants' life styles? Least but not last, how can friendly homes contribute to the "higher" personality traits and virtues of their inhabitants?

There are multiple new areas of home environment study in both applied psychology and environmental psychology research. We hope that the development of RHEQ will aid these research endeavors and support social and therapeutic applications.

\section{Acknowledgements}

We are very grateful to Dr. Valeriya Kuznetsova for her professional help in statistics. We also express our gratitude to the volunteers who took part in our study.

\section{References}

Bentler, P. M., \& Bonnet, D. C. (1980). Significance tests and goodness of fit in the analysis of covariance structures. Psychological Bulletin, 88(3), 588-606. 
Bochaver, A. (2015). Predstavleniya o dome kak element personal'nogo opyta [Home as a category of personal experience]. Psikhologicheskii Zhurnal, 36, 5-15. (in Russian)

Boumeester, H. J. (2011). Traditional housing demand research. In S. T. Jansen, R. W. Goetgeluk, \& H. H. Coolen (Eds.), The measurement and analysis of housing preference and choice (pp. 27-55). New York: Springer.

Bradley, R. H., Caldwell, B. M., \& Elardo, R. (1979). Home environment and cognitive development in the first two years: A cross lagged panel analysis. Developmental Psychology, 15, 246-250.

Brunswik, E. (1956). Perception and the representative design of psychological experiments. Berkeley, CA: University of California Press.

Casakin, H., \& Bernard, F. (2012). The role of place identity in the perception, understanding, and design of built environments. Oak Park, IL: Bentham Science. doi:10.2174/97816080541381120101

Case, D. (1996). Contributions of journeys away to the definition of home: an empirical study of a dialectical process. Journal of Environmental Psychology, 16, 1-15.

Chemero, A. (2003). An outline of a theory of affordances. Ecological Psychology, 15, 181-195. doi:10.1207/S15326969ECO1502_5

Chemero, A. (2009). Radical embodied cognitive science. Cambridge, MA: The MIT Press.

Coolen, H. (2011). The measurement and analysis of housing preference and choice. New York: Springer.

Coolen, H., \& Hoekstra, J. (2001). Values as determinants of preferences for housing attributes. Journal of Housing and the Built Environment, 16, 285-306. doi:10.1023/A:1012587323814

Coolen, H., \& Meesters, J. (2012). Editorial special issue: House, home and dwelling. Journal of Housing and the Built Environment, 27(1), 1-10. doi:10.1007/s10901-011-9247-4

Depres, C. (1991). The meaning of home: literature review and directions for future research and theoretical development. Journal of Architectural and Planning Research, 8, 96-114.

Dovey, K. (1985). Home and homelessness. In I. Altman \& M. Carol (Eds.), Human behavior and environment: Advances in theory and research (Vol. 8, pp. 33-64). New York: Plenum Press.

Edwards, J. R., Caplan, R. D., \& Harrison, R. V. (1998). Person-environment fit theory: conceptual foundations, empirical evidence, and directions for future research. In C. L. Cooper (Ed.), Theories of organizational stress (pp. 28-67). New York: Oxford University Press.

Gibson, J. J. (1986). The ecological approach to visual perception. Hillsdale, NJ: Lawrence Erlbaum Associates.

Gosling, S. D., Ko, S. J., Mannarelli, T., \& Morris, M. E. (2002). A room with a cue: personality judgments based on offices and bedrooms. Journal of Personality and Social Psychology, 82, 379-398. doi:10.1037//0022-3514.82.3.379

Graham, A., \& Graham, C. (1989). Home and family: creating the domestic sphere. Basingstoke, UK: Palgrave Macmillan.

Greeno, J. G. (1994). Gibson's affordances. Psychological Reviere, 101, 336-342.

Hayward, G. (1975). Home as an environmental and psychological concept. Landscape, 20, 2-9.

Heft, H. (1979). Background and focal environmental conditions in the home and attention in young children. Journal of Applied Social Psychology, 9, 47-69.

Heft, H. (1985). High residential density and perceptual-cognitive development: An examination of the effects of crowding and noise in the home. In J. F. Wohlwill \& W. van Vliet (Eds.), Habitats for children: The impacts of density (pp. 39-75). Hillsdale, NJ: Lawrence Erlbaum Associates.

Heft, H. (2012). Foundations of an ecological approach to psychology. In C. D. Clayton (Ed.), The Oxford handbook of environmental and conservation psychology (pp. 11-41). New York: Oxford University Press. 
Hooper, D., Coughlan, J., \& Mullen, M. (2008). Structural equation modelling: Guidelines for determining model fit. Electronic Journal on Business Research Methods, 6(1), 53-60.

Horelli, L. (2007). Constructing a theoretical framework for environmental child-friendliness. Children, Youth and Environments, 17, 267-292.

Horelli, L. \& Prezza, M. (2004). Child-friendly environments: approaches and lessons. Espoo: Helsinki University of Technology.

Ingold, T. (2002). The perception of the environment. essays on livelihood, dwelling and skill. New York: Taylor \& Francis.

Jansen, S., Coolen, H., \& Goetgeluk, R. (2011). The measurement and analysis of housing preference and choice. New York: Springer.

Jonkmann, K., Thoemmes, F., Lüdtke, O., \& Trautwein, U. (2014). Personality traits and living arrangements in young adulthood: selection and socialization. Developmental Psychology, 50, 683-698. doi:10.1037/a0034239

Jorgensen, B., \& Stedman, R. (2006). A comparative analysis of predictors of sense of place dimensions: Attachment to, dependence on, and identification with lakeshore properties. Journal of Environmental Management, 79(3), 316-327.

Kahana, E., Lovegreen, L., Kahana, B., \& Kahana, M. (2003). Person, environment, and person-environment fit as influences on residential satisfaction of elders. Environment and Behavior, 35, 434-453.

Kelly, G. A. (1991). The psychology of personal constructs (Vol. 1. A theory of personality). London: Routledge.

Kyttä, M. (2004). The extent of children's independent mobility and the number of actualized affordances as criteria for child-friendly environments. Journal of Environmental Psychology, 24, 179-198. doi:10.1016/S0272-4944(03)00073-2

Lawton, M. P., \& Nahemow, L. (1973). Ecology and the aging process. In C. Eisdorfer \& M. P. Lawton (Eds.), The psychology of adult development and aging (pp. 619-674). Washington, DC: American Psychological Association.

Lewicka, M. (2011). Place attachment. Journal of Environmental Psychology, 31, 207-230.

Manzo, L. C. (2003). Beyond house and haven. Journal of Environmental Psychology, 23, 47-61.

Moser, G. (2009). Quality of life and sustainability: toward person-environment congruity.Journal of Environmental Psychology, 29, 351-357.

Nartova-Bochaver, S., Bochaver, A., Dmitrieva, N., \& Reznichenko, S. (2016). Dom kak zhiznennaya sreda cheloveka: psikhologicheskoe issledovanie [Home as a person's living environment: a psychological study]. Moscow: Pamyatniki istoricheskoi mysli. (in Russian)

Nartova-Bochaver, S., Dmitrieva, N., Reznichenko S., \& Bochaver A. (2015). How do home environments contribute to the mental health: case of Russian adolescents. In C. Pracana (Ed.), Proceedings of International Psychological Applications Conference and Trends (InPact 2015) (pp. 374-378). Lisbon: World Institute for Advanced Research and Science.

Nartova-Bochaver, S., Dmitrieva, N., Reznichenko, S., Kuznetsova, V., \& Braginets, E. (2015). Metod otsenki druzhestvennosti zhilishcha: oprosnik "Funktsional'nost' domashnei sredy" [The instrument for assessment of dwelling friendliness: the Functionality of Home Environment questionnaire]. Psikhologicheskii Zhurnal, 36, 71-83. (in Russian)

Nartova-Bochaver, S., Reznichenko, S., Braginets, E., \& Podlipnyak, M. (2015). Real and ideal home representations as moderators of a positive person's functioning. Sotsial'naya Psikhologiya i Obshchestvo, 6, 9-22. doi:10.17759/sps.2015060402 (in Russian)

Rapoport, A. (1995). A critical look at the concept home. In D. N. Benjamin, D. Stea, \& D. Saile (Eds.), The home: Words, interpretations, meanings, and environments (pp. 25-53). Aldershot: Avebury. 
Reznichenko, S. I. (2014). Privyazannost' k mestu i chuvstvo mesta: modeli i fenomeny [Attachment to place and sense of place: Models and phenomena]. Sotsial'naya Psikhologiya i Obshchestvo, 5, 3, 15-26. (in Russian)

Reznichenko, S. I. (2016). Valeologicheskii potentsial privyazannosti k domu u vzroslykh lyudei [Valeological potential of home attachment in adults]. Klinicheskaya i Spetsial'naya Psikhologiya, 5(3), 1-23. doi:10.17759/psycljn.2016050301 (in Russian)

Reznichenko, S., Nartova-Bochaver S., \& Kuznetsova, V. (2016). The instrument for assessment of home attachment. Psychology. Journal of Higher School of Economics, 13(3), 498-519. (in Russian) Scannell, L., \& Gifford, S. (2017). The experienced psychological benefits of place attachment.Journal of Environmental Psychology, 51, 256-269. doi:10.1016/j.jenvp.2017.04.001

Skifter Andersen, H. (2011). Explaining preferences for home surroundings and locations. Urbani Izziv, 22, 100-114. doi:10.5379/urbani-izziv-en-2011-22-01-002

Somerville, P. (1992). Homelessness and the meaning of home: Rooflessness or rootlessness? International Journal of Urban and Regional Research, 16(4), 529- 539.

Appendix A

The Final Tested Items of the Relevance of the Home Environment Questionnaire

\begin{tabular}{|c|c|l|}
\hline № & Scale & \\
\hline 1 & Pl & My home changes along with me. \\
\hline 2 & Pot & I “feel at home” in my home. \\
\hline 3 & SP & My house can 'tell'a guest about my achievements and hobbies. \\
\hline 4 & Pr & There is time and space at my home to be alone with myself. \\
\hline 5 & SP & My home is a manifestation of my personality. \\
\hline 6 & Pl & If desired, my house can easily be rearranged and remade. \\
\hline 7 & Pot & I feel like a host at my home. \\
\hline 8 & Pr & When moving about the house I do not disturb other inhabitants. \\
\hline 9 & Pl & If desired, it is easy to move the furniture and swap rooms. \\
\hline 10 & HD & In a bad mood or after a bad day I try for as long as possible not to go home. \\
\hline 11 & Pr & Nobody uses my hygiene products without permission. \\
\hline 12 & HD & There are many distractions at home and it is difficult for me to plan my next day. \\
\hline 13 & Pot & At home I always rest well and recover quite fast. \\
\hline 14 & Pl & I can make any changes in my home. \\
\hline 15 & Pl & I prefer to design the interior of my home by myself instead of inviting experts. \\
\hline 16 & His & The walls of my own house remind me of many events of the past. \\
\hline 17 & Pr & My home is a place where I can do nothing. \\
\hline 18 & HD & It's hard for me to find inspiration and muster strength at home. \\
\hline 19 & His & There are many things in my home that remind me of my family. \\
\hline 20 & SP & I like it that my home is not the same as everyone else's. \\
\hline & & \\
\hline
\end{tabular}




\begin{tabular}{|c|c|l|}
\hline № & Scale & \\
\hline 21 & HD & I rarely do things that I like at home (sports, music, dance, crafts and so on). \\
\hline 22 & His & My home is a place that reminds me of my childhood. \\
\hline 23 & E & I like that there is a place for each of my activities in my home. \\
\hline 24 & Pot & Everything changes, but my home is still my home. \\
\hline 25 & Pr & At home I can choose what I want to do at a particular moment. \\
\hline 26 & SP & There are many things to see at my home. \\
\hline 27 & SP & It is important for me that in my house there is always something to surprise guests. \\
\hline 28 & His & I've lived in my house since childhood. \\
\hline 29 & HD & My home seems to be too empty for me. \\
\hline 30 & His & At my home I have experienced many important events. \\
\hline 31 & Pot & My home gives me a feeling of consistency. \\
\hline 32 & E & It's comfortable to live, do the housekeeping and relax in my house. \\
\hline 33 & E & At home I have no things that are poorly made. \\
\hline 34 & E & My home is always clean and tidy. \\
\hline 35 & E & I like a lot of things, furniture and decor in my house. \\
\hline
\end{tabular}

Note. Pot - Potential, SP - Self-presentation, Pr - Privacy; HD - Home Detachment; E Ergonomics, $\mathrm{Pl}-$ Plasticity, His - Historicity.

Sofia I. Reznichenko - research fellow, Faculty of Clinical and Special Psychology, Moscow State University of Psychology and Education, Ph.D.

Research area: environmental psychology, home environment, health psychology, special psychology. E-mail: reznichenko.sofya@yandex.ru

Sofya K. Nartova-Bochaver - professor, School of Psychology, Faculty of Social Sciences, National Research University Higher School of Economics, D.Sc., professor.

Research area: individual differences, psychology of sovereignty, environmental psychology E-mail: s-nartova@yandex.ru

Ekaterina I. Braginets - postgraduate student, research assistant, Institute of Education, Center of Education Quality Monitoring, National Research University Higher School of Economics.

Research area: home environment friendliness, learning environment, education quality.

E-mail: ebraginets@hse.ru 


\section{Насколько дом подходит индивидуальности обитателя: опросник «Релевантность домашней среды»}

\section{С.И. Резниченко ${ }^{\mathrm{a}}$ С.К. Нартова-Бочавер ${ }^{\mathrm{b}}$, Е.И. Брагинец}

${ }^{a}$ Московский государственный психолого-педагогический университет, 127051, Россия, Москва, ул. Сретенка, д. 29

${ }^{b}$ Национальный исследовательский университет «Высшая школа экономики», 101000, Россия, Москва, ул. Мясницикая, д. 20

\section{Резюме}

Статья посвящена описанию валидизации нового опросника «Релевантность домашней среды», измеряющему разнообразные параметры дома как экосоциального источника психологического благополучия человека. В исследовании участвовали 1730 респондентов в возрасте от 11 до 72 лет $\left(\mathrm{M}_{\text {возр. }}=20.4, \mathrm{Me}_{\text {возр. }}=19, \mathrm{SD}_{\text {возр. }}=6.96 ; 60 \%\right.$ женского пола $)$. Результаты факторного анализа подтвердили наличие семифакторной структуры опросника, состоящей из шкал: Приватность, Ресурсность, Самопрезентация, Эргономичность, Отчужденность от домашней среды, Пластичность и Историчность. Опросник показал высокие коэффициенты надежности (альфа Кронбаха), варьирующие в диапазоне от .91 до .94. Репрезентативность опросника исследовалась путем анализа возрастных и гендерных трендов. На основе анализа данных респондентов была обнаружена возрастная специфика выраженности четырех из семи шкал. Показатели по шкале Ресурсность оказались значимо выше в женской группе, в то время как показатели Отчужденности от дома - в мужской. Содержательная валидность опросника оценивалась посредством пошкального сопоставления данных респондентов студенческого возраста, проживающих в своих собственных домах, и студентов, проживающих в общежитии. Описаны результаты оценки конвергентной валидности, основанные на результатах корреляционного анализа шкал Релевантности домашней среды со шкалами опросников Функциональность домашней среды и Привязанность к дому. Опросник имеет удовлетворительные психометрические свойства и может быть использован в области психологии домашней среды и психотерапии как инструмент экспертизы жизненной среды человека.

Ключевые слова: домашняя среда, субъект-средовое соответствие, оценка валидности, релевантность, допущения, функциональность, привязанность к дому.

Резниченко София Ивановна - научный сотрудник, факультет клинической и специальной психологии, ФГБОУ ВО «Московский государственный психолого-педагогический университет», кандидат психологических наук.

Сфера научных интересов: экологическая психология, домашняя среда, психология здоровья, специальная психология.

Контакты: reznichenko.sofya@yandex.ru 
Нартова-Бочавер Софья Кимовна - профессор, департамент психологии, факультет социальных наук, Национальный исследовательский университет «Высшая школа экономики», доктор психологических наук, профессор.

Сфера научных интересов: психология индивидуальных различий, психология суверенности, психология среды.

Контакты: s-nartova@yandex.ru

Брагинец Екатерина Игоревна - аспирант, стажер-исследователь, Центр мониторинга качества образования, Институт образования, Национальный исследовательский университет «Высшая школа экономики».

Сфера научных интересов: качество образования, дружественность домашней среды, образовательная среда.

Контакты: ebraginets@hse.ru 